\title{
NEUROCOGNITIVE, MENTAL HEALTH, AND GLUCOSE DISORDERS IN FARMERS EXPOSED TO ORGANOPHOSPHORUS PESTICIDES
}

\author{
Ali Akbar MALEKIRAD ${ }^{1}$, Mahya FAGHIH ${ }^{2}$, Mansuoreh MIRABDOLLAHI ${ }^{1}$, Mahdi KIANI ${ }^{1}$, \\ Arezoo $\mathrm{FATHI}^{3}$, and Mohammad ABDOLLAHI ${ }^{4}$
}

Biology Department, Payame Noor University ${ }^{1}$, Faculty of Medicine, Esfahan University of Medical Science Esfahan ${ }^{2}$, Clinical Psychology Department, Islamic Azad University, Science and Research Branch, Arak ${ }^{3}$. Faculty of Pharmacy and Pharmaceutical Sciences Research Center, Tehran University of Medical Science, Tehran ${ }^{4}$, Iran

Received in August 2012

CrossChecked in November 2012

Accepted in January 2013

\begin{abstract}
About 25 million agricultural workers in the developing world suffer from at least one episode of poisoning each year, mainly by anticholinesterase-like organophosphates (OPs). The objective of this cross-sectional study was to establish the OP toxicity in 187 occupationally exposed farmers in terms of neurocognitive impairment, mental health status, clinical symptoms, diabetes, and haematological factors. The exposed group was compared to 187 healthy age-, sex-, and education-matching controls. Neurocognitive impairment was measured using the Subjective Neurocognition Inventory (SNI) and mental health status using the General Health Questionnaire-28 (GHQ-28). The subjects were also tested for fasting blood glucose (FBG), blood urea nitrogen (BUN), cholesterol (CL), triglycerides (TG), creatinine, oral glucose tolerance test (GTT), high-density lipoprotein (HDL), aspartate aminotransferase (AST), alanine aminotransferase (ALT), and alkaline phosphatase (ALP).

The exposed farmers showed higher FBG $(p<0.001)$, BUN $(p=0.007)$, CL $(p<0.001)$, oral GTT $(p<0.001)$, and lower AST $(p<0.001)$, ALP $(p<0.001)$, and creatinine $(p=0.004)$ than controls. The rates of anxiety/ insomnia and severe depression were also significantly higher in the farmers than in controls ( $p=0.015$ and $p<0.001$, respectively). Meanwhile, the rate of social dysfunction was significantly lower than in controls $(p<0.001)$. Disorders affecting psychomotor speed, selective attention, divided attention, verbal memory, nonverbal memory, prospective memory, spatial functioning, and initiative/energy were all lower in the farmers ( $p<0.001)$. Farmers showed clinical symptoms eczema, saliva secretion, fatigue, headache, sweating, abdominal pain, nausea, superior distal muscle weakness, inferior distal muscle weakness, inferior proximal muscle weakness, breath muscle weakness, hand tingling, foot tingling, epiphoria, polyuria, miosis, dyspnoea, bradycardia, and rhinorrhoea, which all significantly correlated with the number of working years.

These findings indicate that farmers who work with OPs are prone to neuropsychological disorders and diabetes.
\end{abstract}

KEY WORDS: cognitive disorders, diabetes mellitus, organophosphorus poisoning 
A WHO task group has lately estimated that the number of pesticide poisoning may soar to three million cases and result in more than 250,000 deaths (1). However, the problem is more complicated according to a recent survey in Asia, indicating that as many as 25 million farmhands suffer episodic poisoning every year (2). Anticholinesterase compounds, organophosphates (OPs), and carbamates $(\mathrm{CMs})$ are for the most part used in farming, as well as in human and veterinary medicine. These compounds can affect mammalian systems by inhibiting acetylcholinesterase (AChE) at the synapses and muscular junctions, which may result in hypercholinergic preponderance. Apparently, the mechanisms causing brain, muscle or other organ damage by OPs are mostly related to a change in oxidant-antioxidant balance, which in turn results in free radical-mediated injury, as supported by many studies (3-10). Careless use of pesticides like OPs may cause diverse health complications by upsetting the nervous, endocrine, reproductive, and immune systems (11-13). In both types of diabetes, long-term increase in glucose starts complications in target organs. As the production of reactive oxygen species (ROS) and reactive nitrogen species (RNS) rises, so does oxidative stress (14). This, possibly together with the rise of fatty acids, favours the adverse effects of high glucose. Type 2 diabetes is more complex than type 1 and has two known mechanisms. One is insulin resistance, in which insulin is less active on peripheral tissues, and the other one is insulin deficiency, in which pancreatic beta cells cannot release insulin properly. Genes and environment are responsible for these malfunctions (15). It is estimated that the number of people who suffer from type 2 diabetes will rise from 171 million in 2000 to 366 million in 2030 (16). Many studies corroborate that $\mathrm{OP}$ exposure might contribute to type 2 diabetes (17-25). Although the overall evidence of neurological and neurobehavioral effects of long-term OP exposure is thought to be small, it is not that difficult to find some $(26,27)$. Environmental agents which have neurotoxic effects may cause a wide variety of problems, including mental retardation and disability as well as subtle changes in performance, which are mainly related to exposure time and the amount of the chemical agent (28). This points to a correlation between exposure to $\mathrm{OP}$ and mitochondrial toxicity, especially in the central nervous system (2931). OPs are known to inhibit acetyl cholinesterase (AChE), but they can also act through non-cholinergic pathways (32) such as acylpeptide hydrolase (33), which is more sensitive than $\mathrm{AChE}$ to dichlorvos, the parent compound of metrifonate, a therapeutic agent used in the treatment of cognitive impairment and Alzheimer's disease. However, we still know little about the direct action of acylpeptide hydrolase on cognitive processes and the physiological and molecular effect of OPs (33). Moreover, OPs can inhibit neuropathy target esterase (NTE) to cause paralysis of lower-limbs and a distal injury to long nerve axons (34). Main neurotoxic effects in humans caused by OPs include the cholinergic syndrome, the intermediate syndrome, delayed polyneuropathy, and chronic neuropsychiatric disorder $(27,35)$.

Acute health effects are very well known, but the long-term effects of chronic low-level exposure are still to be evaluated $(8,12,13,15)$. The aim of our study was to determine neurocognitive impairment, mental health status, clinical symptoms, diabetes incidence, and haematological disorders in farmers occupationally exposed to OP pesticides in southwest Iran.

\section{SUBJECTS AND METHODS}

This comparative cross-sectional study included 374 subjects, 252 men and 122 women. All gave informed consent before enrolment, and the study protocol was approved by the Institutional Review Board. A summary of demographic data on workers and control subjects is given in Table 1. The first group included 187 (16 to 80-year-old) horticulture farmers who worked in a village in the southwest of Iran. Control subjects consisted of 187 age-matching workers from the same village who were not engaged in any agricultural work and had no history of jobrelated exposure to OP pesticides. Information on working history, socioeconomic status (salary, education), and lifestyle (smoking, alcohol consumption, drug use, vitamin or antioxidant supplementation, and dietary habits) were obtained at an interview with expert examiner. Neurocognitive impairment was measured using the Subjective Neurocognition Inventory (SNI) and mental health status was evaluated using the General Health Questionnaire-28 (GHQ-28) as described elsewhere (36-38). All subjects underwent a thorough clinical examination for any signs or symptoms of chronic illnesses. Subjects with chronic illnesses or receiving drug or radiation therapy, consuming alcohol, drugs of abuse, or antioxidant supplementation or subjects 
exposed to toxins other than OPs at screening were excluded from the study.

Blood samples were collected from the subjects throughout the spraying season on Saturdays (being the first day of the work week in Iran) between 7 and 8 a.m., that is, before work. Blood was tested for fasting blood glucose (FBG), blood urea nitrogen (BUN), cholesterol (CL), triglycerides (TG), creatinine, high-density lipoprotein (HDL), aspartate aminotransferase (AST), alanine aminotransferase (ALT), and alkaline phosphatase (ALP).

To identify high-risk subjects for neurocognitive impairment, we used the Iranian version of SNI. This self-report inventory contains 76 questions about everyday memory and attention problems. Subjects had to answer each question on a five-point Likert scale from "very frequently" to "never". The questions covered selective attention (ten items), divided attention (four items), long-term memory (seven items), prospective memory (seven items), and psychomotor retardation (nine items). The GHQ-28 was also used to identify the following four symptoms in the high-risk subjects: "somatic symptoms", "anxiety and insomnia", "social dysfunction", and "severe depression".

\section{Statistical analysis}

To compare worker and control data, we used the two-sided forms of Mann-Whitney U and Student's $t$-tests. The association between variables was established using Spearman's correlation coefficient. All data, except for demographic, are presented as median and quartiles or mean $\pm \mathrm{SD}$. The $p$ values lower than 0.05 were considered statistically significant. The analysis was run on StatsDirect version 2.7.9 (Cheshire, UK).

\section{RESULTS}

Farmers and controls did not significantly differ in age, but controls smoked for significantly longer than farmers did, even though the amount of cigarettes smoked did not differ significantly (Table 1).

Table 2 shows the somatic symptoms, anxiety and insomnia, social dysfunction, and severe depression in workers and controls. The rates of anxiety and insomnia $(p=0.015)$ and severe depression $(p<0.001)$ were significantly higher in the farmers than controls, while the rate of social dysfunction was significantly lower than in controls $(p<0.001)$.

Table 3 shows that psychomotor speed (PS), selective attention (SA), divided attention (DA), verbal memory (VM), nonverbal memory (NVM), prospective memory (PM), spatial functioning (SF), and initiative/energy (I/E) were significantly lower in workers than controls $(p<0.001)$.

Table 4 shows haematological parameters in the two groups. Median FBG $(p<0.001)$, BUN $(p=0.007)$,

Table 1 Summary of demographic data in workers and control subjects

\begin{tabular}{llccc}
\hline Subjects & & Farmers $(\boldsymbol{n}=\mathbf{1 8 7})$ & Controls $(\boldsymbol{n}=\mathbf{1 8 7})$ & $\boldsymbol{p}$ value* \\
\hline Age / years & & $37.94 \pm 12.41$ & $37.05 \pm 11.78$ & 0.48 \\
\hline Sex & Male & 126 & 126 & - \\
\hline & Female & & 61 & - \\
\hline Work history / year & & $9.78 \pm 7.72$ & - & 0.026 \\
\hline Smoking / years & & $0.39 \pm 2.45$ & $1.36 \pm 5.3$ & 0.27 \\
\hline Smoking / cigarette per day & $0.62 \pm 3.75$ & $1.07 \pm 4.1$ & \\
\hline
\end{tabular}

Data represent mean $\pm S D$.

*Two-sided Student's t-test

Table 2 The status of mental health in workers and controls

\begin{tabular}{lccccc}
\hline Group & $\begin{array}{c}\text { Somatic } \\
\text { symptoms }\end{array}$ & $\begin{array}{c}\text { Anxiety and } \\
\text { insomnia }\end{array}$ & $\begin{array}{c}\text { Social } \\
\text { dysfunction }\end{array}$ & Severe depression & GHQ-28 \\
\hline $\begin{array}{l}\text { Control } \\
(n=187)\end{array}$ & $7(6$ to 7$)$ & $7(4$ to 7$)$ & $7(7$ to 7$)$ & $3(0$ to 7$)$ & $24(19$ to 28$)$ \\
\hline $\begin{array}{l}\text { Farmers } \\
(n=187)\end{array}$ & $7(4$ to 10$)$ & $8(4$ to 11$)$ & $6(4$ to 8$)$ & $5.5(2$ to 9.25$)$ & $\begin{array}{c}26.5(16.75 \text { to } \\
37.25)\end{array}$ \\
\hline$p$ value* & 0.907 & 0.030 & 0.002 & 0.0001 & 0.060 \\
\hline
\end{tabular}

Data represent median and quartiles (Q1-Q3). GHQ-28: General Health Questionnaire-28.

*Two-sided Mann-Whitney U test 
Table 3 Neurocognitive impairment in controls and farmers

\begin{tabular}{lccccccccc}
\hline Group & PS & SA & DA & VM & NVM & PM & SF & I/E & Total \\
\hline Controls & $31(29$ to & $44(40.5$ & $18(17$ to & $35(32$ to & $18(16$ & $31(29$ to & $18(16$ to & $48(45$ to & $333(309$ to \\
$(n=187)$ & $34)$ & to 47$)$ & $19)$ & $38.5)$ & to 20$)$ & $34)$ & $20)$ & $51)$ & $353)$ \\
\hline Farmers & $23(19$ to & $29.5(24$ & $14(10.25$ & $26.5(20.25$ & $14.5(11$ & $23(20$ to & $14(11$ to & $35(28.25$ & $244.5(211.25$ \\
$(n=187)$ & $28)$ & to 35$)$ & to 17.75$)$ & to 32$)$ & to 16$)$ & $28)$ & $17)$ & to 43$)$ & to 286.5$)$ \\
\hline$P$ value* & 0.0001 & 0.0001 & 0.0001 & 0.0001 & 0.0001 & 0.0001 & 0.0001 & 0.0001 & 0.0001 \\
\hline
\end{tabular}

Data represent the median and quartiles (Q1-Q3). PS: psychomotor speed; SA: selective attention; DA: divided attention; VM: verbal memory; NVM: nonverbal memory; PM: prospective memory; SF: spatial functioning; and I/E: initiative/energy

*Two-sided Mann-Whitney U test

Table 4 Haematological parameters in farmers and controls

\begin{tabular}{|c|c|c|c|c|c|c|c|c|c|c|}
\hline 气̄ & 司 & 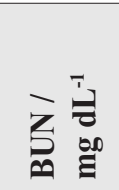 & 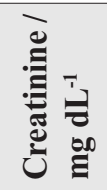 & Ð & 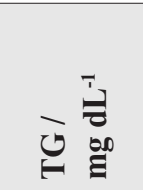 & 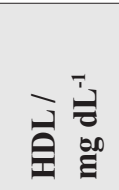 & 氞主 & 实宗 & 章主 & 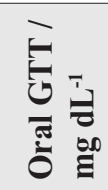 \\
\hline $\begin{array}{l}\text { Farmers } \\
(n=187)\end{array}$ & $\begin{array}{l}84.90 \\
(76.25 \\
\text { to } 94)\end{array}$ & $\begin{array}{l}31.02 \\
(23 \text { to } \\
38)\end{array}$ & $\begin{array}{l}0.83 \\
(0.7 \text { to } \\
0.9)\end{array}$ & $\begin{array}{l}174.5 \\
(151 \text { to } \\
194.5)\end{array}$ & $\begin{array}{l}123.59 \\
(79 \text { to } \\
157.75)\end{array}$ & $\begin{array}{l}44.85 \\
(40 \text { to } \\
50)\end{array}$ & $\begin{array}{l}24.52 \\
(18 \text { to } \\
29)\end{array}$ & $\begin{array}{l}20.19 \\
(12 \text { to } \\
24)\end{array}$ & $\begin{array}{l}93.14 \\
(73.25 \text { to } \\
109)\end{array}$ & $\begin{array}{l}86.27 \\
(79 \text { to } \\
95)\end{array}$ \\
\hline $\begin{array}{l}\text { Controls } \\
(n=187)\end{array}$ & $\begin{array}{l}78.31 \\
(62 \text { to } \\
84)\end{array}$ & $\begin{array}{l}28.99 \\
(23 \text { to } \\
34)\end{array}$ & $\begin{array}{l}0.87 \\
(0.8 \text { to } \\
0.9)\end{array}$ & $\begin{array}{l}160.61 \\
(143 \text { to } \\
180.75)\end{array}$ & $\begin{array}{l}138.73 \\
(79.25 \text { to } \\
170.75)\end{array}$ & $\begin{array}{l}47.42 \\
(40 \text { to } \\
54)\end{array}$ & $\begin{array}{l}31.31 \\
(25 \text { to } \\
34.75)\end{array}$ & $\begin{array}{l}20.82 \\
(15 \text { to } \\
25)\end{array}$ & $\begin{array}{l}113.74 \\
(92 \text { to } \\
131)\end{array}$ & $\begin{array}{l}68.43 \\
(70 \text { to } \\
100)\end{array}$ \\
\hline$P$ value* & 0.0001 & 0.014 & 0.008 & 0.0001 & 0.77 & 0.051 & 0.0001 & 0.108 & 0.0001 & 0.0001 \\
\hline
\end{tabular}

Data represent median and quartiles (Q1-Q3).

*Two-sided Mann-Whitney U test

FBG - fasting blood glucose

$B U N$ - blood urea nitrogen

$C L$ - cholesterol

$T G$ - triglycerides

$H D L$ - high-density lipoprotein

AST - aspartate aminotransferase

ALT - alanine aminotransferase

ALP - alkaline phosphatase

GTT-glucose tolerance test

CL $(p<0.001)$, and oral GTT $(p<0.001)$ were significantly higher in workers than controls, whereas AST $(p<0.001)$, ALP $(p<0.001)$, and creatinine $(p=0.004)$ were significantly lower than in controls.

There was a positive correlation between the number of working years on one side and eczema $\left(r^{2}=0.403, p<0.0001\right)$, saliva secretion $\left(r^{2}=0.307\right.$, $p<0.0001)$, fatigue $\left(r^{2}=0.433, p<0.0001\right)$, headache $\left(r^{2}=0.472, p<0.0001\right)$, sweating $\left(r^{2}=0.343, p<0.0001\right)$, abdominal pain $\left(r^{2}=0.235, p<0.0001\right)$, nausea $\left(r^{2}=0.265, p<0.0001\right)$, superior distal muscle weakness $\left(r^{2}=0.215, p<0.0001\right)$, inferior distal muscle weakness $\left(r^{2}=0.196, p<0.001\right)$, inferior proximal muscle weakness $\left(r^{2}=0.166, p<0.004\right)$, breath muscle weakness $\left(r^{2}=0.138, p<0.017\right)$, hand tingling $\left(r^{2}=0.438\right.$, $p<0.0001)$, foot tingling $\left(r^{2}=0.435, p<0.0001\right)$, epiphoria $\left(r^{2}=0.279, p<0.0001\right)$, polyuria $\left(r^{2}=0.210\right.$, $p<0.0001)$, miosis $\left(r^{2}=0.202, p<0.0001\right)$, dyspnoea $\left(r^{2}=0.345, p<0.0001\right)$, bradycardia $\left(r^{2}=0.191\right.$, $p<0.001)$, and nasal flowing $\left(r^{2}=0.311, p<0.0001\right)$ on the other.

The interviews clearly showed that only $2.67 \%$ of the workers used proper protection at work such as masks.

\section{DISCUSSION}

Compared to controls, farmers in this study have shown significantly higher neurocognitive impairment, psychological distress, and FBG, BUN, CL, and oral GTT levels and significantly lower AST, ALP, and 
creatinine. These findings suggest that exposure to OPs had resulted in a sort of toxicity in the farmers, especially as there is a positive correlation between years of work and clinical symptoms. Interviews with the farmers have shown that they did not use proper protection like masks, gloves, long boots, head cover, or face cover, and that they did not shower regularly, even though showers were available. The only safety they used was a kind of cloth mask.

Our findings support a significant positive correlation between working history and clinical symptoms in pesticide sprayers found by Singh et al. (39) in organ systems such as the respiratory, ocular, gastrointestinal, and skin. Our farmers also complained of pesticide poisoning symptoms. They showed a marked rise in neurocognitive impairment and psychological distress. Similarly, Rothlein et al. (40) reported an association between low-level pesticide exposure and deficits in neurobehavioral performance. Rohlman et al. (41) reported that exposure to low pesticide levels over many years in agriculture is associated with neurological impairment parameters such as selective attention, symbol and digit, and reaction time. Moreover, Davies et al. (42) claim to provide powerful evidence of the causal relationship between OP exposure and neuropsychiatric disorders, including mood destabilisation and cognitive impairment. In fact, many studies report higher incidence of neuropsychological disorders in OPexposed workers $(43,44)$ through oxidative stress and consequent apoptotic neuronal cell death (3). OPs also induce neurocognitive disorders by inhibiting the activity of NTE acylpeptide hydrolase $(33,34)$.

Our finding of increased FBG is in agreement with an earlier study in workers chronically exposed to OPs (45). Small doses of bisphenol-A affected glucose metabolism in rodents in the study by AlonsoMagdalena et al. (46), which suggests that a change in glucose homeostasis may cause type 2 diabetes. This imbalance might also be caused by low-dose OP exposure through endocrine disorder (47). Various OPs can contribute to the development of obesity, dyslipidaemia, and insulin resistance - common precursors of type 2 diabetes and cardiovascular diseases $(48,49)$. Very recently, Pakzad et al. (50) reported that diazinon disturbs glucose homeostasis in adipose tissues through oxidative stress. All these findings make a point that OPs put glucose out of balance; they may induce diabetes by stimulating hepatic gluconeogenesis and glycogenolysis or disruption of insulin effects in peripheral organs (9).
Our present study has confirmed that farmers are prone to neuropsychological disorders and diabetes caused by OP exposure. Future studies should be investigating the effects of natural antioxidants in OP-exposed workers in the hope that they can lessen OP toxicity.

\section{Competing interests}

None of the authors have any competing interests to declare.

\section{Acknowledgement}

The authors would like to thank all subjects for their kind co-operation. The study was supported by the Tehran University of Medical Sciences (TUMS), the Payame Noor University, and Iran National Science Foundation (INSF).

\section{REFERENCES}

1. WHO. The Impact of Pesticides on Health: Preventing Intentional and Unintentional Deaths from Pesticide Poisoning, 2004 [displayed 5 February 2013]. Available at http://www.who.int/mental_health/prevention/suicide/en/ PesticidesHealth2.pdf

2. Jeyaratnam J. Acute pesticide poisoning: a major global health problem. World Health Stat Q 1990;43:139-44.

3. Abdollahi M, Ranjbar A, Shadnia S, Nikfar S, Rezaie A. Pesticides and oxidative stress: a review. Med Sci Monit 2004; 10:141-7.

4. Jamshidi HR, Ghahremani MR, Ostad SN, Sharifzadeh M, Dehpour AR, Abdollahi M. Effects of diazinon on the activity and gene expression of mitochondrial glutamate dehydrogenase from rat pancreatic Langerhans islets. Pest Biochem Physiol 2009; 93:23-7.

5. Shadnia S, Dasgar M, Taghikhani S, Mohammadirad A, Khorasani R, Abdollahi M. Protective effects of alphatocopherol and n-acetyl-cysteine on diazinon-induced oxidative stress and acetylcholinesterase inhibition in rats. Toxicol Mech Methods 2007;17:109-15.

6. Rahimi R, Nikfar S, Abdollahi M. Increased morbidity and mortality in acute human organophosphate-poisoned patients treated by oximes: a meta-analysis of clinical trials. Hum Exp Toxicol 2006;25:157-62.

7. Mohammadi H, Karimi G, Rezayat SM, Dehpour AR, Shafiee H, Nikfar S, Baeeri M, Sabzevari O, Abdollahi M. Benefit of nanocarrier of magnetic magnesium in rat malathioninduced toxicity and cardiac failure using non-invasive monitoring of electrocardiogram and blood pressure. Toxicol Ind Health 2011;27:417-29.

8. Shojaei Saadi H, Abdollahi M. The importance of pesticides effects on human reproduction in farmers. Int $\mathrm{J}$ Pharmacol 2012;8: 467-9.

9. Pournourmohammadi S, Ostad SN, Azizi E, Ghahremani MH, Farzami B, Minaie B, Larijani B, Abdollahi M. 
Induction of insulin resistance by malathion: evidence for disrupted islets cells metabolism and mitochondrial dysfunction. Pest Biochem Physiol 2007;88:346-52.

10. Shafiee H, Mohammadi H, Rezayat SM, Hosseini A, Baeeri M, Hassani S, Mohammadirad A, Bayrami Z, Abdollahi M. Prevention of malathion-induced depletion of cardiac cells mitochondrial energy and free radical damage by a magnetic magnesium-carrying nanoparticle. Toxicol Mech Methods 2010;20:538-43.

11. Soltaninejad K, Abdollahi M. Current opinion on the science of organophosphate pesticides and toxic stress: A systematic review. Med Sci Monit 2009;15:75-90.

12. Mostafalou S, Abdollahi M. Current concerns on genotoxicity of pesticides. Int J Pharmacol 2012;8:473-4.

13. Mostafalou S, Abdollahi M. Concerns of environmental persistence of pesticides and human chronic diseases. Clin Exp Pharmacol 2012;S5:e002.

14. Rahimi R, Nikfar S, Larijani B, Abdollahi M. A review on the role of antioxidants in the management of diabetes and its complications. Biomed Pharmacother 2005;59:365-73.

15. Mostafalou S, Abdollahi M. The role of environmental pollution of pesticides in human diabetes. Int J Pharmacol 2012;8:139-40

16. Wild S, Roglic G, Green A, Sicree R, King H. Global prevalence of diabetes: estimates for the year 2000 and projections for 2030. Diabetes Care 2004;27:1047-53.

17. Rahimi R, Abdollahi M. A review on the mechanisms involved in hyperglycemia induced by organophosphorus pesticides. Pestic Biochem Physiol 2007;88:115-21.

18. Abdollahi M, Donyavi M, Pournourmohammadi S, Saadat M. Hyperglycemia associated with increased hepatic glycogen phosphorylase and phosphoenolpyruvate carboxykinase in rats following subchronic exposure to malathion. Comp Biochem Physiol C Toxicol Pharmacol 2004;137:343-7.

19. Ansari G, Mojtahedzadeh M, Kajbaf F, Najafi A, Khajavi MR, Khalili H, Rouini MR, Ahmadi H, Abdollahi M. How does blood glucose control with metformin influence intensive insulin protocols? Evidence for involvement of oxidative stress and inflammatory cytokines. Adv Ther 2008;25:681-702.

20. Mostafalou S, Eghbal MA, Nili-Ahmadabadi A, Baeeri M, Abdollahi M. Biochemical evidence on the potential role of organophosphates in hepatic glucose metabolism toward insulin resistance through inflammatory signalling and free radical pathways. Toxicol Ind Health 2012;28:840-51.

21. Teimouri F, Amirkabirian N, Esmaily H, Mohammadirad A, Aliahmadi A, Abdollahi M. Alteration of hepatic cells glucose metabolism as a non-cholinergic detoxication mechanism in counteracting diazinon-induced oxidative stress. Hum Exp Toxicol 2006;25:697-703.

22. Panahi P, Vosough-Ghanbari S, Pournourmohammadi S, Ostad SN, Nikfar S, Minaie B, Abdollahi M. Stimulatory effects of malathion on the key enzymes activities of insulin secretion in Langerhans islets, glutamate dehydrogenase and glucokinase. Toxicol Mech Methods 2006;16:161-7.

23. Amirkabirian N, Teimouri F, Esmaily H, Mohammadirad A, Aliahmadi A, Abdollahi M. Protection by pentoxifylline of diazinon-induced toxic stress in rat liver and muscle. Toxicol Mech Methods 2007;17:215-21.

24. Vosough-Ghanbari S, Sayyar P, Pournourmohammadi S, Aliahmadi A, Ostad SN, Abdollahi M. Stimulation of insulin and glucagon synthesis in rat Langerhans islets by malathion in vitro: Evidence for mitochondrial interaction and involvement of subcellular non-cholinergic mechanisms. Pestic Biochem Physiol 2007;89:130-6.

25. Pourkhalili N, Pournourmohammadi S, Rahimi F, VosoughGhanbari S, Baeeri M, Ostad SN, Abdollahi M. Comparative effects of calcium channel blockers, autonomic nervous system blockers, and free radical scavengers on diazinoninduced hyposecretion of insulin from isolated islets of Langerhans in rats. Arh Hig Rada Toksikol 2009;60:15764.

26. Bayrami M, Hashemi T, Malekirad AA, Ashayeri H, Faraji F, Abdollahi M. Electroencephalogram, cognitive state, psychological disorders, clinical symptom, and oxidative stress in horticulture farmers exposed to organophosphate pesticides. Toxicol Ind Health 2012;28:90-6.

27. Abdollahi M, Karami-Mohajeri S. A comprehensive review on experimental and clinical findings in intermediate syndrome caused by organophosphate poisoning. Toxicol Appl Pharmacol 2012;258:309-14.

28. Mendola P, Selevan SG, Gutter S, Rice D. Environmental factors associated with a spectrum of neurodevelopmental deficits. Ment Retard Dev Disabil Res Rev 2002;8:188-97.

29. Ranjbar A, Ghahremani MH, Sharifzadeh M, Golestani A, Ghazi-Khansari M, Baeeri M, Abdollahi M. Protection by pentoxifylline of malathion-induced toxic stress and mitochondrial damage in rat brain. Hum Exp Toxicol 2010;29:851-64.

30. Rezvanfar MA, Rezvanfar MA, Ranjbar A, Baeeri M, Mohammadirad A, Abdollahi M. Biochemical evidence on positive effects of rolipram a phosphodiesterase-4 inhibitor in malathion induced toxic stress in rat blood and brain mitochondria. Pestic Biochem Physiol 2010;98:135-43.

31. Karami-Mohajeri S, Abdollahi M. Toxic influence of organophosphate, carbamate, and organochlorine pesticides on cellular metabolism of lipids, proteins, and carbohydrates. Hum Exp Toxicol 2011;30:1119-40.

32. Abdollahi M, Mostafalou S, Pournourmohammadi S, Shadnia S. Oxidative stress and cholinesterase inhibition in saliva and plasma of rats following subchronic exposure to malathion. Comp Biochem Physiol C Toxicol Pharmacol 2004;137:2934.

33. Pancetti F, Olmos C, Dagnino-Subiabre A, Rozas C, Morales B. Noncholinesterase effects induced by organophosphate pesticides and their relationship to cognitive processes: implication for the action of acylpeptide hydrolase. J Toxicol Environ Health B Crit Rev 2007;10:623-30.

34. Gupta RC. Toxicology of Organophosphate and Carbamate Compounds. San Diego (CA): Elsevier Academic Press; 2009.

35. Jokanović M, Kosanović M. Neurotoxic effects in patients poisoned with organophosphorus pesticides. Environ Toxicol Pharmacol 2010;29:195-201.

36. Moritz S, Ferahli S, Naber D. Memory and attention performance in psychiatric patients lack of correspondence between clinician-rated and patient-rated functioning with neuropsychological test results. J Int Neuropsychol Soc 2004; 10:623-33.

37. Goldbeg D, Williams PA. A User's Guide to the General Health Questionnaire. Windsor: NEFR-Nelson; 1988.

38. Zimmermann P, Messner C, Poser U, Sedelmeier P. Ein Fragebogen erlebter Defizite der Aufmerksamkeit (FEDA) 
[A questionnaire measuring self-experienced deficits of attention, in German]. Freiburg: PsychologischesInstitut der Universität Freiburg; 1991.

39. Singh VK, Jyoti, Reddy MM, Kesavachandran C, Rastogi SK, Siddiqui MK. Biomonitoring of organochlorines, glutathione, lipid peroxidation and cholinesterase activity among pesticide sprayers in mango orchards. Clin Chim Acta 2007;377:268-72.

40. Rothlein J, Rohlman DS, Lasarev M, Phillips J, Muniz J, McCauley L. Organophosphate pesticide exposure and neurobehavioral performance in agricultural and nonagricultural Hispanic workers. Environ Health Perspect 2006;114:691-6.

41. Rohlman DS, Lasarev M, Anger WK, Scherer J, Stupfel J, McCauley L. Neurobehavioral performance of adult and adolescent agricultural workers. Neurotoxicology 2007;28:374-80.

42. Davies DR, Ahmed GM, Freer T. Chronic organophosphate induced neuropsychiatric disorder (COPIND): Results of two postal questionnaire surveys. J Nutr Environ Med 1999;9:12334.

43. Rosenstock L, Keifer M, Daniell WE, McConnell R, Claypoole K. Chronic central nervous system effects of acute organophosphate pesticide intoxication. Lancet 1991;338:2237.

44. Fiedler N, Kipen H, Kelly-McNeil K, Fenske R. Long-term use of organophosphates and neuropsychological performance. Am J Ind Med 1997;32:487-96.
45. Rezg R, Mornagui B, Kamoun A, El-Fazaa S, Gharbi N. Effect of subchronic exposure to malathion on metabolic parameters in the rat. C R Biol 2007;330:143-7.

46. Alonso-Magdalena P, Ropero AB, Soriano S, Quesada I, Nadal A. Bisphenol-A: a new diabetogenic factor? Hormones (Athens) 2010;9:118-26.

47. Lee DH, Steffes MW, Sjödin A, Jones RS, Needham LL, Jacobs DR Jr. Low dose of some persistent organic pollutants predicts type 2 diabetes: a nested case-control study. Environ Health Perspect 2010;118:1235-42.

48. Lee DH, Steffes MW, Sjödin A, Jones RS, Needham LL, Jacobs DR Jr. Low dose organochlorine pesticides and polychlorinated biphenyls predict obesity, dyslipidemia, and insulin resistance among people free of diabetes. PLoS One 2011;6:e15977.

49. Mostafalou S, Abdollahi M. The role of environmental pollution of pesticides in human diabetes. Int J Pharmacol 2012;8:139-40.

50. Pakzad M, Fouladdel S, Nili-Ahmadabadi A, Pourkhalili N, Baeeri M, Azizi E, Sabzevari O, Ostad SN, Abdollahi M. Sublethal exposures of diazinon alters glucose homostasis in Wistar rats: Biochemical and molecular evidences of oxidative stress in adipose tissues. Pestic Biochem Physiol 2013;105:57-61. 


\section{Sažetak}

\section{POREMEĆAJI NEUROKOGNITIVNE FUNKCIJE, MENTALNOGA ZDRAVLJA I RAZINE GLUKOZE U ZEMLJORADNIKA IZLOŽENIH ORGANOFOSFORNIM PESTICIDIMA}

Oko 25 milijuna zemljoradnika iz zemalja u razvoju imalo je barem jednu epizodu trovanja na godinu, uglavnom antikolinesteraznim organofosfatima. Cilj ovoga križnog ispitivanja bio je utvrditi u 187 profesionalno izloženih zemljoradnika toksično djelovanje organofosfata na neurokognitivnu funkciju, mentalno zdravlje, kliničke simptome, dijabetes i hematološke parametre. Izložena je skupina uspoređena s odgovarajućom kontrolnom skupinom od 187 ispitanika odgovarajuće dobi, spola i obrazovanja. Neurokognitivni poremećaj mjeren je s pomoću Inventara za subjektivnu procjenu neurokognitivne funkcije (izv. Subjective Neurocognition Inventory, krat. SNI), a mentalno zdravlje ocijenjeno s pomoću Upitnika o općem zdravstvenom stanju s 28 stavki (izv. General Health Questionnaire-28, krat. GHQ-28). Ispitanicima su također napravljene pretrage glukoze u krvi natašte (FBG), ureje u krvi (BUN), kolesterola (CL), triglicerida (TG), kreatinina, zatim test podnošljivosti oralne glukoze (GTT), lipoproteina visoke gustoće (HDL), aspartat aminotransferaze (AST), alanin aminotransferaze (ALT) i alkalne fosfataze (ALP).

Izloženi zemljoradnici imali su značajno više nalaze FBG-a $(p<0,001)$, BUN-a $(p=0,007), \mathrm{CL}-\mathrm{a}(p<0,001)$ i GTT-a $(p<0,001)$ te značajno niže nalaze AST-a $(p<0,001)$, ALP-a $(p<0,001)$ i kreatinina $(p=0,004)$ od kontrolnih ispitanika. Također su u odnosu na kontrolu značajno češće imali tjeskobe/nesanice, odnosno snažnu depresiju $(p=0,015$, odnosno $p<0,001)$. $\mathrm{S}$ druge strane, učestalost poremećaja socijalne funkcije bila je značajno manja nego u kontrolnih ispitanika $(p<0,001)$. Svi poremećaji koji utječu na brzinu psihomotornog odgovora, selektivnu pažnju, podijeljenu pažnju, verbalno pamćenje, neverbalno pamćenje, prospektivno pamćenje, prostornu funkciju te inicijativu/energiju bili su slabije izraženi u zemljoradnika $(p<0,001)$. Zemljoradnici su iskazali kliničke simptome poput ekcema, slinjenja, umora, glavobolje, znojenja, boli u trbuhu, mučnine, slabosti gornjih i donjih, distalnih i proksimalnih mišića te respiratornih mišića, trnaca u šakama i stopalima, epiforije, poliurije, mioze, dispneje, bradikardije i curenja iz nosa, a svi su simptomi bili značajno povezani s godinama staža.

Ovi rezultati ispitivanja upućuju na to da su zemljoradnici koji rade s organofosfatima skloniji neuropsihološkim poremećajima i dijabetesu.

KLJUČNE RIJEČI: kognitivni poremećaji, šećerna bolest, trovanje organofosfornim spojevima

\section{CORRESPONDING AUTHOR:}

Professor Mohammad Abdollahi

Department of Toxicology and Pharmacology

Faculty of Pharmacy, and Pharmaceutical Sciences

Research Center

Tehran University of Medical Science

Tehran 1417614411, Iran

E-mail: Mohammad.Abdollahi@UToronto.Ca 